\title{
Rancang Bangun Game Mobile Bola Adil Berbasis Android Dengan Metode Linear Feedback Shift Register (LFSR)
}

\author{
I Made Gede Suryadinatha, A. A. Ketut Agung Cahyawan Wiranatha, Kadek Suar Wibawa \\ Program Studi Teknologi Informasi, Fakultas Teknik, Universitas Udayana \\ Bukit Jimbaran, Bali, Indonesia Telp. (0361) 701806 \\ e-mail:kologcs@gmail.com, agung.cahyawan@unud.ac.id, suar wibawa@yahoo.com
}

\begin{abstract}
Abstrak
Permainan Bola Adil merupakan permainan yang dipimpin oleh seorang blandang/bandar serta papan gambar dan bola sebagai media permainannya. Permainan Bola Adil umumnya diadakan saat ada upacara tertentu dan menjadi bagian dari Budaya Bali. Permainan Bola Adil menarik karena kemenangan pemain dipengaruhi pemilihan gambar dan gambar yang ditunjuk saat bola yang sebelumnya dilempar berhenti. Game bukan lagi hal yang baru bagi masyarakat, namun masyarakat saat ini cenderung bermain game moderen pada perangkat mobile daripada game tradisional dikarenakan lebih praktis. Menariknya permainan Bola Adil dan kecenderungan masyarakat bermain game pada perangkat mobile melatarbelakangi Rancang Bangun Game Mobile Bola Adil Berbasis Android. Game Bola Adil dikembangkan menggunakan metode Linear Feedback Shift Register (LFSR). Metode LFSR berfungsi untuk menghasilkan bilangan acak, dimana pada Game Bola Adil diperlukan delapan bilangan acak untuk delapan posisi awal pelemparan bola. Pemain dapat menggunakan game yang dihasilkan dengan memilih karakter dan menentukan jumlah koin serta posisi gambar untuk taruhan, pemain menang jika bola pada permainan berhenti pada gambar yang sama dengan gambar pilihan pemain, dan pemain kalah jika yang terjadi sebaliknya. Koin yang diperoleh jika menang yaitu sembilan kali koin yang dipertaruhkan, sedangkan koin yang hilang sejumlah yang dipertaruhkan jika kalah.
\end{abstract}

Kata Kunci : Bola Adil, Game, Permainan Tradisional, Linear Feedback Shift Register

Bola Adil Game is a game led by someone called blandang/bandar as well as a drawing board and a ball as its game medium. It is usually held during certain ceremonies; therefore, it is a part of Balinese culture. This game is interesting because the player's victory is influenced by the selection of the image and the designated image when the previously thrown ball stops. Game is not a new thing for society and they like to play modern games on their mobile phone than the traditional one because it is more practical. Interestingly the game of Fair Ball and the tendency of people play games on mobile devices is the background of making the Design of Bola Adil Mobile Game based Android. The Bola Adil game was developed using The Linear Feedback Shift Register (LFSR) method. This method functions to generate random numbers and eight random numbers for eight starting positions of the ball are required in this game. Players can use the generated game by selecting the character and determining the number of coins as well as the position of the drawing for the bet; the player wins if the ball on the game stops on the same image with the player's preferred image and the player loses if the opposite happens. Coins earned by the winners are nine times the amount of coins at stake; meanwhile, the amount of coins at stake will be lost if they do not win this game.

Keywords: Bola Adil, Game, Traditional Game, Linear Feedback Shift Register

\section{Pendahuluan}

Indonesia memiliki banyak permainan tradisional salah satunya adalah Bola Adil. Permainan Bola Adil merupakan permainan yang dipimpin oleh seorang blandang/bandar serta papan gambar dan bola sebagai media permainannya. Permainan Bola Adil telah lama dikenal oleh masyarakat, dimana permainan Bola Adil biasanya dilakukan pada saat ada suatu upacara adat maupun keagamaan di Bali. Permainan Bola Adil menarik karena kemenangan pemain

Rancang Bangun Game Mobile Bola Adil Berbasis Android Dengan Metode Linear Feedback 
dipengaruhi pemilihan gambar dan gambar yang ditunjuk saat bola yang sebelumnya dilempar berhenti.

Game bukan lagi dikatakan sebagai hal yang baru di Masyarakat Indonesia. Sebuah game yang ter-install pada perangkat mobile dapat dijadikan sebagai hiburan karena dapat dimainkan kapan pun dan dimana saja menggunakan smartphone secara praktis [1]. Masyarakat di zaman sekarang cenderung bermain game modern pada perangkat mobile daripada game tradisional dikarenakan lebih praktis. Teknologi zaman sekarang yang paling populer dan berkembang yaitu perangkat mobile. Perangkat mobile yang memiliki beragam fitur menarik di dalamnya meliputi multimedia, games, hingga internet [2].

Menariknya permainan Bola Adil dan kecenderungan masyarakat bermain game pada perangkat mobile melatarbelakangi Rancang Bangun Game Mobile Bola Adil Berbasis Android. Salah satu penelitian tentang game mobile berbasis Android yaitu Game Kartu Spirit yang membuat para pemain mudah untuk memainkannya tanpa membeli/mencari kartu domino, hanya cukup dengan meng-install permainan tersebut pada smartphone [3]. Game Bola Adil disini sedikit berbeda dengan permainan aslinya yaitu pelemparan bola menggunakan Metode Linear Feedback Shift Register (LFSR). Metode LFSR berfungsi untuk menghasilkan bilangan acak, dalam penelitian ini delapan bilangan yang dibutuhkan untuk posisi awal pelemparan bola. Penggunaan Metode Linear Feedback Shift Register karena telah berhasil diterapkan pada permainan tradisional yaitu Game Blok Bakar untuk mengacak kemunculan kartu [4].

\section{Metodologi Penelitian}

Metodologi penelitian dari game Bola Adil dapat dilihat pada alur yang telah dibuat. Berikut adalah diagram alur penelitian dari game Bola Adil.

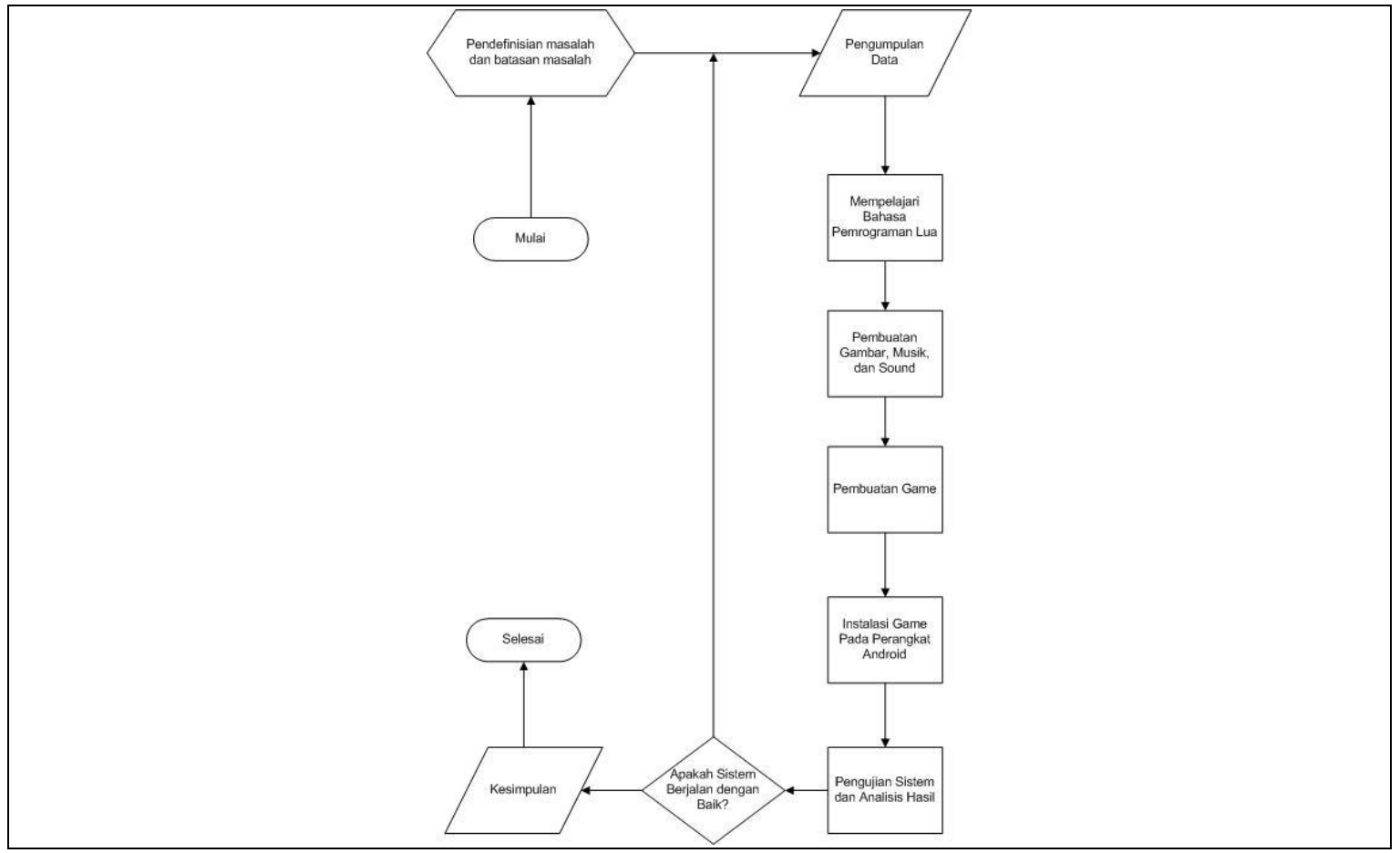

Gambar 1. Metodologi Penelitian

Gambar 1 menunjukkan alur peneitian Game Bola Adil, yang mulai dilakukan dalam penelitian adalah sebagai berikut.

a. Pendefinisian masalah dan batasan masalah dari game yang dibuat.

b. Pengumpulan data dan melakukan survey yang berhubungan dengan perancangan dan pembuatan game, melalui studi literatur.

c. Mempelajari bahasa pemrograman lua yang digunakan dalam perancangan coding program pada game yang dibuat. 
d. Penentuan musik dan sound, pembuatan gambar yang meliputi gambar karakter, background, dan komponen permainan yang diperlukan dalam game tersebut.

e. Perancangan coding program untuk Game Bola Adil yang telah direncanakan.

f. Instalisasi game yang telah selesai pada platform android.

g. Pengujian terhadap game, dari yang telah dibuat dan terpasang pada platform android kemudian dilakukan analisis hasil pengujian game, baik dilakukan oleh programmer maupun masyarakat awam.

h. Pengambilan kesimpulan.

\subsection{Gambaran Umum} Gambar 2

Gambaran umum dari Game Bola Adil yang memuat seluruh sistem dapat dilihat pada

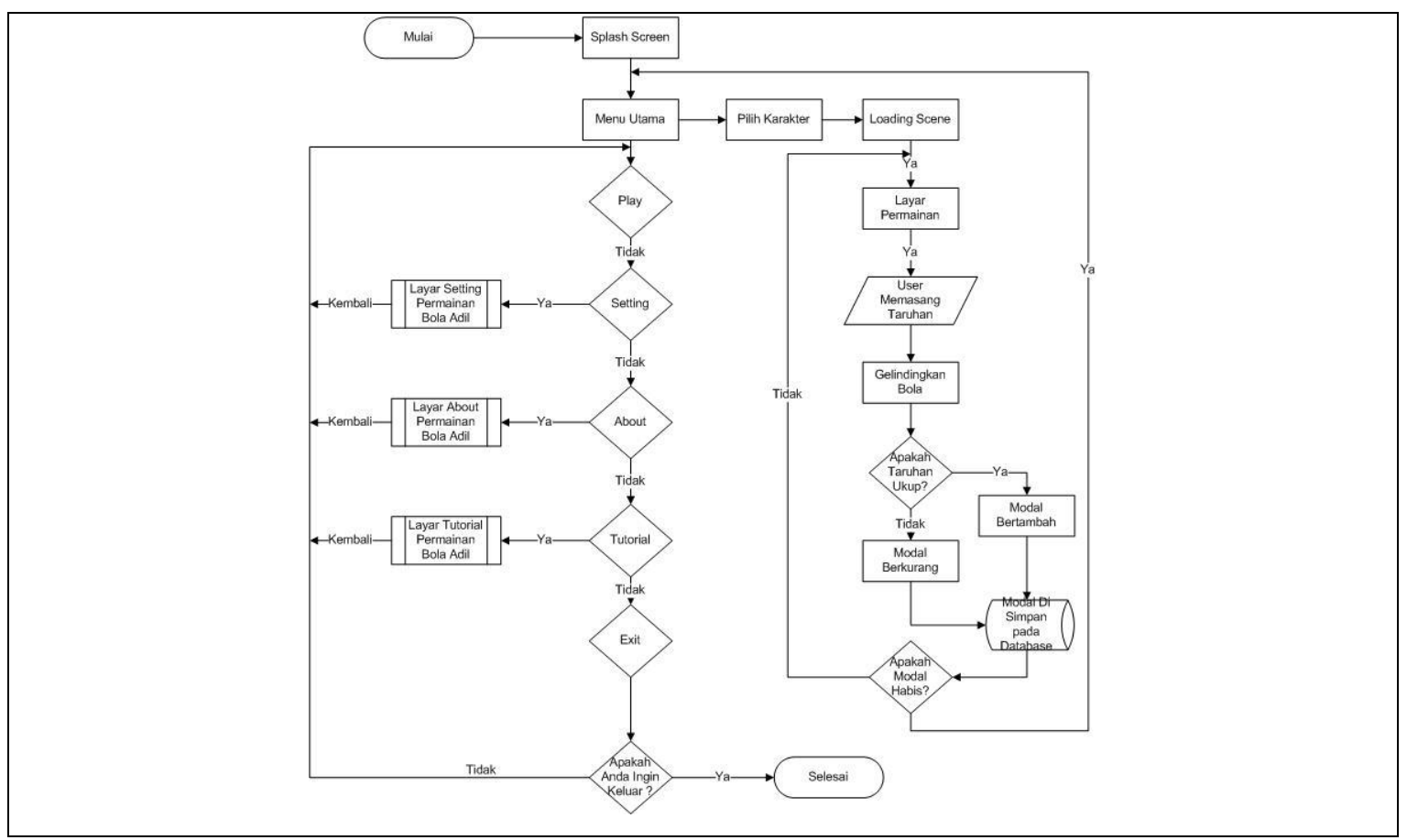

Gambar 2. Gambaran Umum Aplikasi

Gambar 2 menampilkan gambaran umum dari aplikasi Game Bola Adil dapat dijelaskan sebagai berikut, pertama user diberikan 5 pilihan menu, yaitu Menu Play Game, Menu Setting, Menu About, Menu Tutorial, dan Menu Exit. User pada Menu Playgame disuguhkan 4 karakter yang berbeda sebelum memulai permainan. Menu Setting berisi tentang pengaturan sound dari game. Menu About berisi tentang data pribadi dari perancang game. Menu Tutorial berisi tentang informasi cara bermain game. Menu yang terakhir adalah Menu Exit yang berfungsi untuk keluar dari permainan Bola Adil.

\section{Kajian Pustaka}

3.1 Permainan Tradisional

Permainan tradisional adalah bagian dari warisan dan tradisi budaya [5]. Bola adil merupakan salah satu permainan tradisional sederhana yang biasa dimainkan oleh masysarakat. Bandar/blandang adalah orang yang memimpin permainan. Bandar/blandang melakukan pelemparan bola setelah semua pemain melakukan pemasangan taruhan. Pelemparan bola dilakukan untuk mengetahui pemenang dari permainan Bola Adil.

\subsection{Android}

Android adalah sistem operasi open source untuk perangkat mobile dan dikembangkan oleh Open Handset Alliance. Open Handset Alliance yang terdiri dari pengembang perangkat 
lunak, pengembang perangkat keras, dan penyedia seperti Google, HTC, Intel, Motorola, Qualcomm, T-Mobile dan NVIDIA. Android diakuisisi oleh Google pada bulan Juli 2005 dan Google merilis secara resmi pada 5 November 2007. Android menawarkan Android SDK yang menyediakan tools dan API untuk pengembang aplikasi dengan platform Android. Java adalah bahasa pemrograman yang digunakan pada Android [6].

\subsection{Lua}

Lua dirancang, diimplementasikan, dan dipelihara oleh tim di PUC-Rio, Universitas Katolik Kepausan Rio de Janeiro di Brasil. Lua merupakan turunan dari data description atau configuration language yaitu SOL (Simple Object Language) dan DEL (Data Entry Language). Lua adalah bahasa mesin cepat dengan ukuran kecil yang dapat ditanam dengan mudah ke dalam aplikasi. Lua mempunyai API sederhana dan terdokumentasi, yang memungkinkan integrasi yang kuat dengan kode yang ditulis dalam bahasa lain. Lua menggabungkan sintaks prosedural sederhana dengan deskripsi data, yang di dasari oleh array asosiatif dan semantik extensible. Lua dinamis diketik, berjalan dengan menginterpretasikan bytecode untuk mesin virtual berbasis mendaftar, dan memiliki manajemen memori otomatis dengan pengumpulan sampah tambahan, sehingga ideal untuk konfigurasi, scripting, dan prototyping cepat [7].

\subsection{Linear Feedback Shift Register (LFSR}

Stephen Herlambang menyatakan bahwa Linear Feedback Shift Register (LFSR) adalah shift register yang masukannya merupakan fungsi linear dari state sebelumnya. Satusatunya fungsi linear pada bit satuan adalah xor, oleh karena itu LFSR adalah shift register yang bit masukannya dibangkitkan oleh exclusive-or (xor) dari beberapa bit dari keseluruhan nilai shift register. Poses metode LFSR 4 bit dapat dilihat pada Tabel 1 [8].

Tabel 1. Skema Proses LFSR

\begin{tabular}{ccccc}
\hline Waktu ke & S4 S3 S2 S1 \\
\hline 0 & 0 & 0 & 0 & 1 \\
1 & 1 & 0 & 0 & 0 \\
2 & 1 & 1 & 0 & 0 \\
3 & 1 & 1 & 1 & 0 \\
4 & 1 & 1 & 1 & 1
\end{tabular}

Tabel 1 menjelaskan skema proses LFSR dengan nilai awal yaitu 1 yang bitnya bernilai 0001. Proses dari skema tersebut yaitu.

1. Langkah awal, melakukan exclusive-or S1 dan S4.

2. S1-S4 digeser ke kanan sepanjang satu bit.

3. Output pertama adalah bit pertama

4. Bit hasil exclusive-or antar S1 dan S4 di input ke S4 (sebelum digeser).

5. Proses dari 1-4 tersebut diulang 4 kali atau sesuai jumlah bit yang digunakan.

Hasil akhir dari Tabel 1 memperlihatkan Skema Proses LFSR dari nilai input 1 adalah 15 (1111). Proses perhitungan dilakukan sebanyak 8 kali karena hanya membutuhkan 8 buah bilangan. Proses perhitungan dilakukan berurutan dimulai dari $\mathrm{X}_{0}$ sampai $\mathrm{X}_{7}$. Deretan hasil bilangan acak dapat dilihat sebagai berikut.

$$
\begin{aligned}
& X_{0}=2, \\
& X_{1}=14, \\
& X_{2}=5, \\
& X_{3}=3, \\
& X_{4}=1, \\
& X_{5}=15, \\
& X_{6}=10, \\
& X_{7}=9 .
\end{aligned}
$$


Hasil bilangan acak yang lebih besar dari 8 di-filter dengan cara memasukkan bilangan yang belum muncul dari angka 1 sampai 8 , hal tersebut dilakukan karena pada pelemparan bola pada game Bola Adil hanya ada 8 posisi.

\section{Hasil dan Pembahasan}

Hasil perancangan aplikasi Game Bola Adil yang dihasilkan terdiri dari Scene Splash Screen, Scene Main Menu, Scene Play Game, Scene Setting, Scene About, dan Scene Tutorial.

\subsection{Scene Splash Screen}

Scene Splash Screen merupakan tampilan awal yang muncul saat membuka aplikasi Game Bola Adil. Tampilan splash screen dapat dilihat pada Gambar 3.

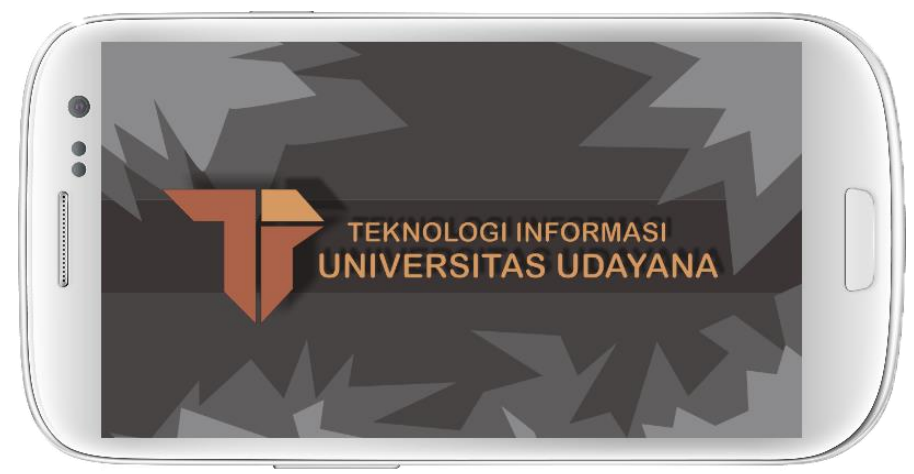

Gambar 3. Tampilan Splash Screen

Splash screen dari Game Bola Adil muncul selama 2 detik sebelum menuju Scene Main Menu. Desain splash screen bergambarkan Logo Teknologi Informasi, Universitas Udayana.

\subsection{Scene Main Menu}

Scene Main Menu merupakan scene utama yang berisikan semua menu yang ada pada Game Bola Adil. Scene Main Menu dapat dilihat pada Gambar 4.

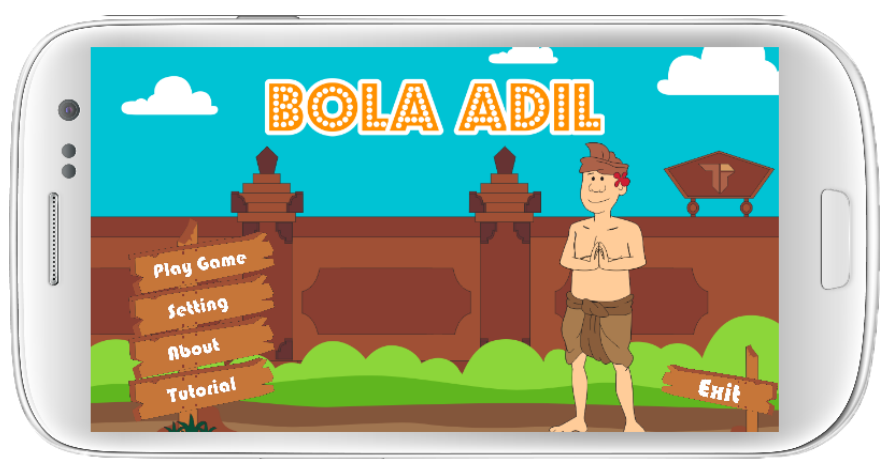

Gambar 4. Scene Main Menu

Lima button terdapat pada Scene Main Menu diantaranya Button Play Game, Button Setting, Button About, Button Tutorial, dan Button Exit. Button Play Game mengarahkan user ke scene pilih karakter, setelah itu dapat memulai permainan. Button Setting membawa user ke pengaturan sound. Button About menampilkan informasi tentang pembuat game. Button Tutorial berisikan tentang fungsi-fungsi dari icon yang terdapat dalam Game Bola Adil. Button Exit berfungsi untuk keluar dari Game Bola Adil.

\subsection{Scene Game Play}

Scene Game Play awal menampilkan scene pilih karakter sebelum permainan dimulai. User wajib memilih karakter yang diinginkan. 


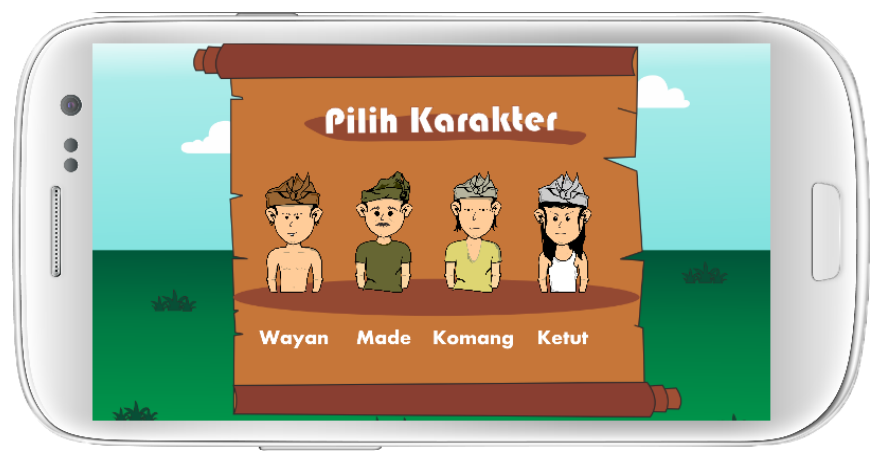

Gambar 5. Scene Pilih Karakter

Gambar 5 merupakan tampilan dari pilih karakter. Empat jenis karakter terdapat pada scene pilih karakter dengan nama Bali yaitu Wayan, Made, Komang, Ketut. User harus memilih satu karakter untuk melanjutkan ke tampilan game play.

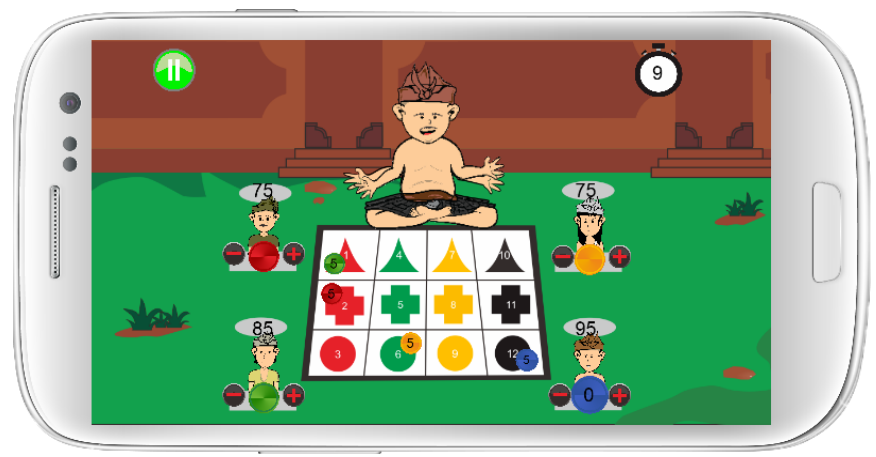

Gambar 6. Tampilan Game Play

Gambar 6 merupakan tampilan inti dari Game Bola Adil. User berada diposisi sebelah kanan bawah dan masing-masing pemain memiliki modal awal yang sama yaitu 100. Para pemain diberikan waktu 15 detik dalam melakukan pemasangan. User dapat memasang taruhan dengan mengatur jumlah taruhan terlebih dahulu kemudian melakukan drag terhadap koin ke salah satu gambar yang telah disediakan.

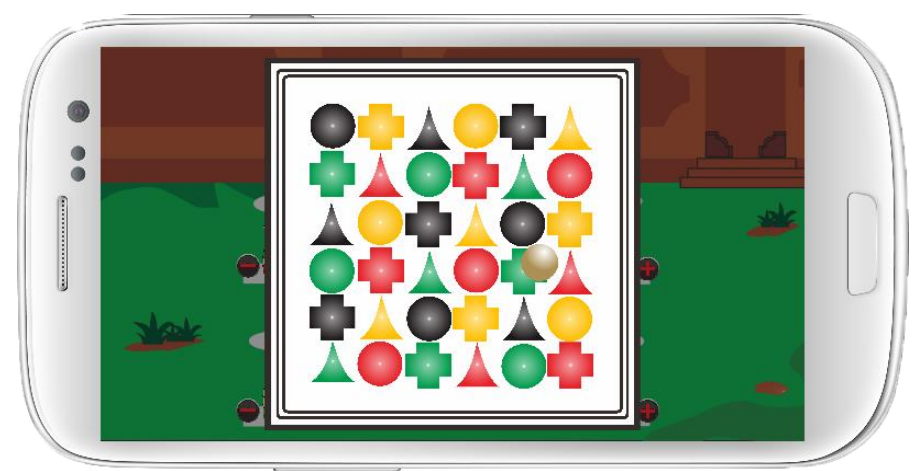

Gambar 7. Tampilan Bola Bergelinding

Permainan berlanjut ke tampilan bola bergelinding seperti pada Gambar 7 setelah waktu pemasangan taruhan habis. Posisi pelemparan bola dilakukan secara acak dan pergerakan bola tersebut berhenti tak menentu. Bola berhenti pada suatu gambar dan pemain yang memasang taruhan pada gambar tersebut adalah pemenangnya. 


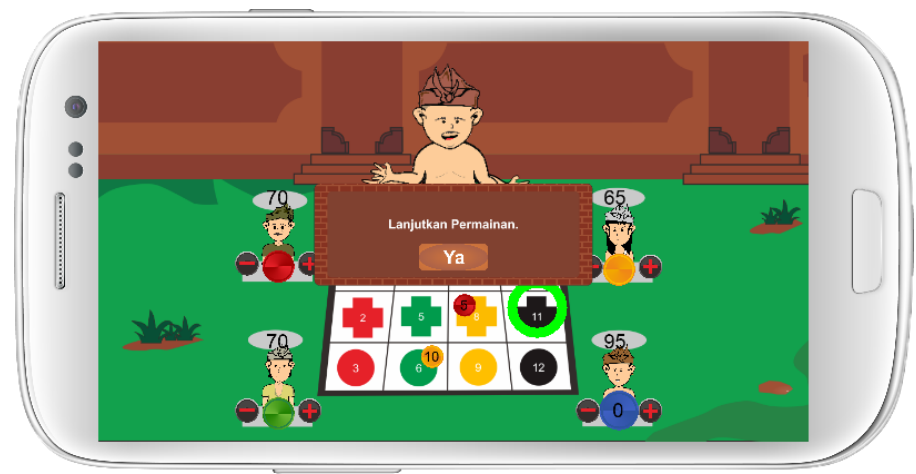

Gambar 8. Tampilan Taruhan yang Muncul

Berhentinya pergerakan bola setelah bola dilempar, dilanjutkan dengan tampilan gambar yang ukup dan disertai tampilan pop up untuk melanjutkan permainan yang dapat dilihat seperti pada Gambar 8. Pemain yang ukup mendapatkan rewards 9 kali lipat dari nilai taruhan yang dipasang.

\subsection{Scene Setting}

Scene Setting merupakan scene yang berisikan pengaturan sound pada game. Scene Setting muncul bila user memilih Button Setting pada main menu.

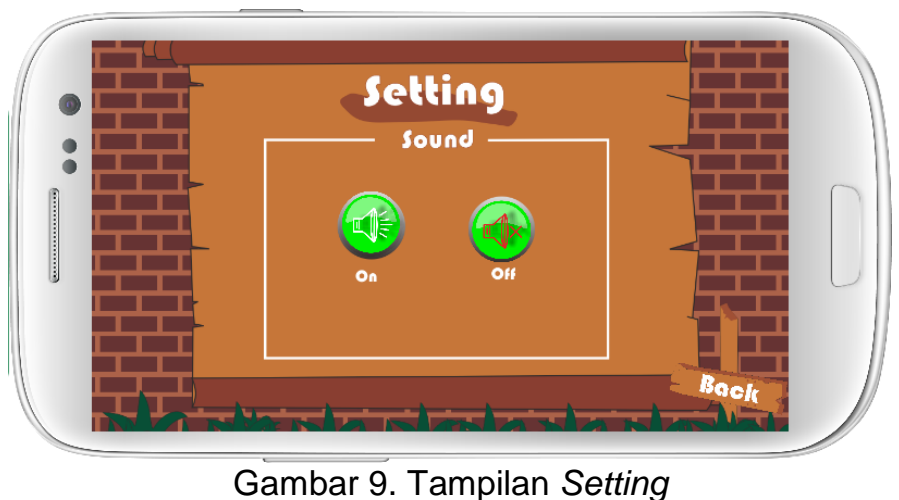

Gambar 9 merupakan tampilan setting yang menampilkan Button Sound On, Button Sound Off, dan Button Back. Button Sound On memiliki fungsi untuk menghidupkan suara dan Button Sound Off memiliki fungsi untuk mematikan suara. Button Back berfungsi untuk pindah scene, kembali ke menu utama.

\subsection{Scene About}

Scene About merupakan scene yang menampilkan informasi mengenai Game Bola Adil. Scene About muncul bila user memilih Button About pada main menu.

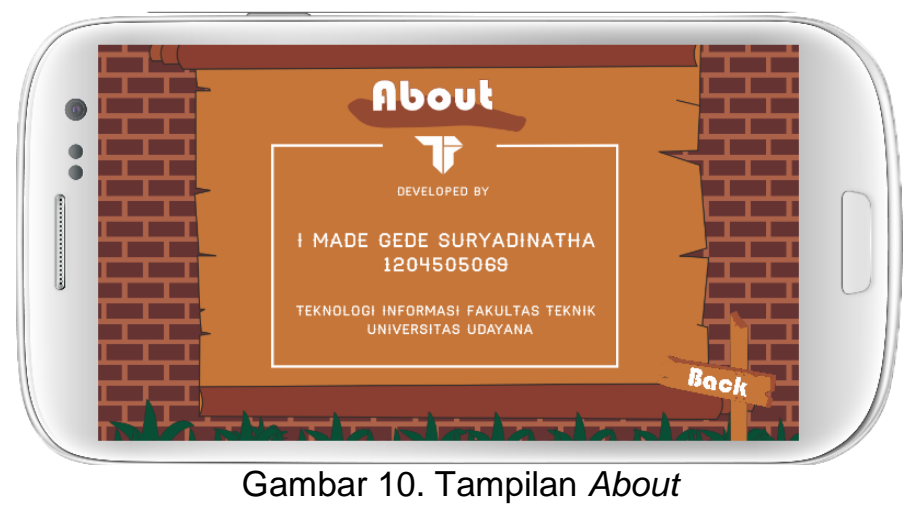

Rancang Bangun Game Mobile Bola Adil Berbasis Android Dengan Metode Linear Feedback Shift Register (LFSR) (I Made Gede Suryadinatha) 
Gambar 10 merupakan tampilan about dari Game Bola Adil. Scene tampilan about berisi tentang informasi mengenai perancangan Game Bola Adil yaitu data pribadi perancang Game Bola Adil.

\subsection{Scene Tutorial}

Scene Tutorial menampilkan fungsi-fungsi dari setiap icon yang terdapat pada Game Bola Adil. Scene Tutorial muncul bila user memilih Button Tutorial pada main menu.
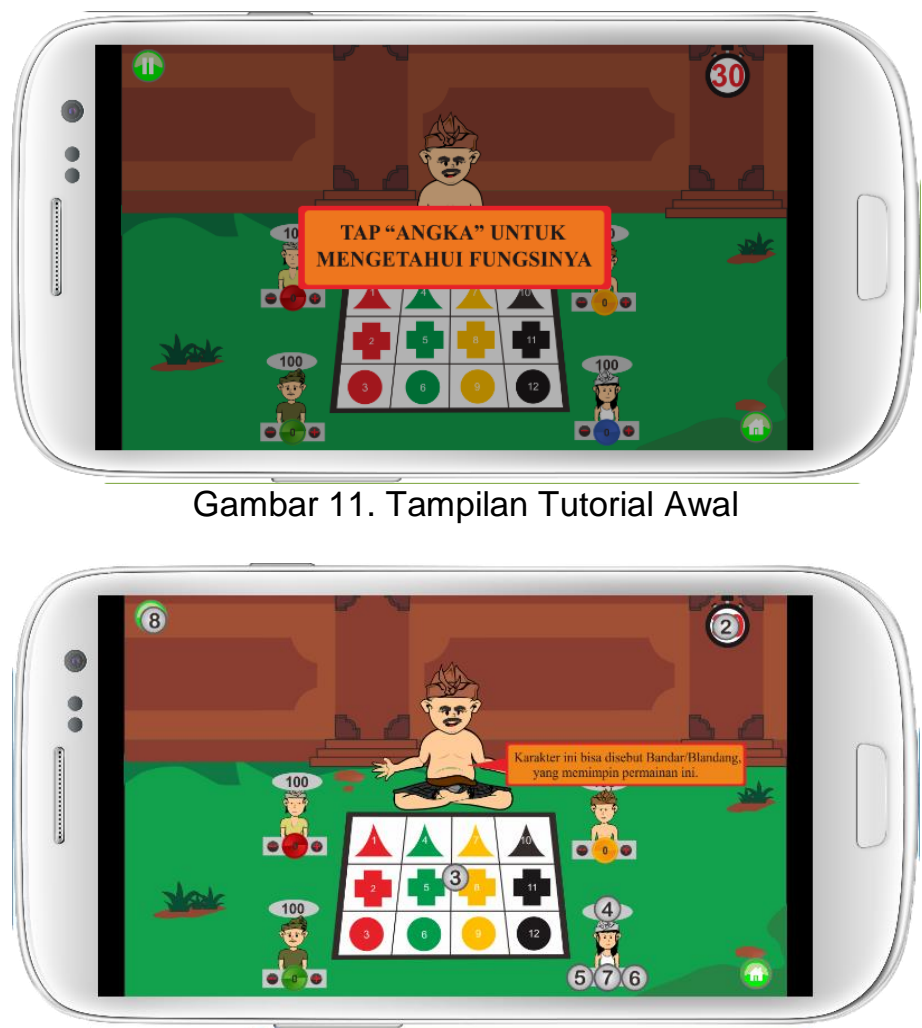

Gambar 12. Tampilan Tutorial Inti

Gambar 11 memperlihatkan isi dari Button Tutorial dari Game Bola Adil. Setiap icon yang terdapat dalam Game Bola Adil memiliki fungsi untuk melakukan permainan. Delapan nomer digunakan untuk menunjukkan fungsi tiap icon seperti pada Gambar 12. Penjelasan tentang fungsi icon didapatkan oleh user setelah memilih nomer terkait icon tersebut.

\section{Kesimpulan}

Game Bola Adil memperkenalkan sebuah permainan tradisional sederhana yang terdapat di Indonesia, khususnya Daerah Bali. Game Bola Adil dibuat dengan desain karakter dan objek yang cukup menarik, dan dapat dimainkan dengan mudah yaitu dengan menyentuh layar untuk memindahkan objek berupa koin ke salah satu gambar. Aplikasi Game Bola Adil dibuat menggunakan software Corona SDK dengan bahasa pemrograman Lua. Game dapat dipasang pada device Android. Metode Linear Feedback Shift Register (LFSR) yang diterapkan pada aplikasi Game Bola Adil menghasilkan delapan bilangan acak untuk delapan posisi awal pelemparan bola. Pemain dapat menggunakan game yang dihasilkan dengan memilih karakter dan menentukan jumlah koin serta posisi gambar untuk taruhan. Setiap pemain diberikan koin awal sejumlah 100 dan diberikan waktu selama 15 detik untuk memasang taruhan. Pemain menang jika bola pada permainan berhenti pada gambar yang sama dengan gambar pilihan pemain, dan pemain kalah jika yang terjadi sebaliknya. Koin yang diperoleh jika menang yaitu sembilan kali koin yang dipertaruhkan, sedangkan koin yang hilang sejumlah yang dipertaruhkan jika kalah. Papan gelinding bola pada permainan memiliki permukaan yang tidak rata atau cembung sehingga tempat berhentinya bola tidak mudah diprediksi. Pemain keluar 
dari permainan jika koin pemain telah habis atau pemain dapat memilih button pause dilanjutkan dengan button home pada layar permainan.

\section{Daftar Pustaka}

[1] I. D. M. Y. A. Putra, A. A. K. A. C. Wiranatha, and P. W. Buana, "Rancang Bangun Game Tapel Bali pada Platform Android," Lontar Komputer, vol. 6, no. 1, pp. 170-179, 2015.

[2] A. A. O. Sudana, I. M. Sukarsa, and I. M. W. Saputra, "Information System of Yadnya Ceremony on Android-Based," International Journal of Hybrid Information Technology, vol. 7, no. 6, pp. 155-164, 2014.

[3] A. J. Pratama, A. A. K. O. Sudana, and I. N. Piarsa, "Rancang Bangun Game Kartu Spirit Berbasis Android dengan Fitur Online Multiplayer," Lontar Komputer, vol. 6, no. 1, pp. 517-528, 2015.

[4] K. A. Praptha, I. K. G. D. Putra, and G. M. A. Sasmita, "Game Blok Bakar Berbasis Android Menggunakan Metode LCG dan LFSR," Merpati, vol. 3, no. 3, pp. 162-169, 2015.

[5] T. Kovacevic and S. Opic, "Contribution of Traditional Games to the Quality of Students' Relations and Frequency of Students' Socialization in Primary Education," Croatian Journal of Education-Hrvatski Casopis Za Odgoj I Obrazovanje, vol. 16, no. 1, pp. 95112, 2014.

[6] A. F. Waruwu, I. P. A. Bayupati, and I. K. G. Darma Putra, "Augmented Reality Mobile Application of Balinese Hindu Temples: DewataAR," International Journal Computer Network and Information Security, no. January, pp. 59-66, 2015.

[7] A. A. M. D. Krisnandari, "Aplikasi Game Edukasi Membuat Canang Berbasis Android," Merpati, vol. 2, no. 1, pp. 50-57, 2014.

[8] D. I. Harapan, "Implementasi Vigenere Chiper dengan Random Key Metode Linear Feedback Shift Register ( LFSR ) pada Teks," Majalah IImiah INTI, vol. 58, pp. 58-61, 2013. 